\title{
The Native Lion and the Deer
}

\author{
R Prabhakar*
}

Characters in this One Act Play

Richaiah: Richaiah is the head of a remote village called 'Hariwada'. $\mathrm{He}$ is the sole semi-literate in that village. He exploits vulnerable people for his advantage and identity through foxy plans. He is the person responsible for the banishment of Revulaiah, killing of Servaiah, and Slavaiah. At the end, the trio (Revulaiah, Servaiah and Slavaiah) bounce back and are responsible for the killing of Richaiah with the same weapon of exploitation.

Witchamma: She is the wife of Richaiah, the bale of 'Hariwada'. She is in deep onesided infatuation and lust with Revulaiah. She often pretends as if the local deity 'Dungamma' possessed her. Witchamma is the main source of Richaiah for exploitation. Through her, he employs foxy plans upon the superstitious people. Finally, she deceives her husband for the lust of Revulaiah.

Slavaiah: Slavaiah is buoyant spirit. He, an outcast, is the slave under the tyrannical and brutal control of Richaiah. He became slave to Richaiah due to the debt of his father. Richaiah seduces and kills Slavaiah's beautiful wife, Siri, and also foeticides. He was also mercilessly poisoned by Richaiah to death in the process of extinction of his enemies. Therefore, he became buoyant spirit.

Assistant Professor, Department of English, Vikrama Simhapuri University, Nellore, Andra Pradesh; prabhakarjoli@gmail.com 
Servaiah: Servaiah is also buoyant spirit. He also hails from strata of downtrodden community. He is very poor and occupies the land belonging to the local deity, Dungamma, for cultivation. Witchamma, the wife of Richaiah, finds faults with Servaiah on the occupation of her land. He was killed by Richaiah.

Revulaiah: Revulaiah is a rebellious hearted man who wants to create awareness among the superstitious people of Hariwada. People hurled stones at him to expel from the village to graveyard on the guilty of degrading the sanctity and power of local deity, Dungamma. At the end, he punishes Richaiah by the same weapon of exploitation.

Folk: $\quad$ The barbarous knaves of Hariwada. They are the staunch believers in local deity, Dungamma.

\section{Act I}

\section{Scene I}

(There is a dry banyan tree amidst the burial ground, wherein there are unstoppable and woeful whispers, screams, and grind of tooth amid the heaps of rotten bones scattered from top to the bottom of the graveyard, the pregnant of rotten bodies, cupped with deep abyss inundated and engulfed with chaos. The place is replete with skulls agape that are like perfect epitomes of starvation. There is a venomous red-dead well adjacent to one of the verges and brims of graveyard. Its venomous water is likely to enthral desperate people for self-killing in it. The buoyant spirit, Slavaiah, is in perturbed mood recollecting his erstwhile agony, despair, and grim fate caused by Richaiah, Bale of Hariwada, and the native lion. It is a small village with two hundred thatched huts and only one lavish bungalow which is of the Bale. Many destitute immigrants eked out for their survival in that vulnerable and hopeless village. The eligibility to live in that village is vulnerability, knavery, and stupidity. The assassinated Slavaiah, the spirit, has been the resident of grave yard for the last many years. He hangs and bums around the graveyard expecting the arrival of any herald and hope that will catapult him from his agony, but he waits for hope in vain. A ludicrous and paralyzed owl, which is symbol of hopelessness, peeps at the soul with penetrating wild looks. During his roaming around the Hades, Servaiah, a new soul encounters to Slavaiah 
amid the burial land. The painful whisperings are of a couple of deceived buoyant souls perching under the huge-dry banyan tree in a doleful and apathetic mood cupping their heads in between their knees. They reminisce about their unhappy and freedomless past lives in the thick darkness that vouches for stupidity and vulnerability. The souls are nocturnal in the darkness.)

Slavaiah: (Whirling and swirling his spiral foot hither and thither) Who are you?

Servaiah: (Coupling the curling spiral foot with Slavaiah's curly foot) I am Servaiah.

Slavaiah: How long have you been here in this place of wisdom?

Servaiah: I have been here for the last one week. Why do you call this banal graveyard "Place of wisdom"? (With cryptic look) Who are you!?

Slavaiah: I am Slavaiah. Many of our ancestors got transformed in this place of wisdom (graveyard). Do you know Satya Harichandra?

Servaiah: $\quad E h$ ! I remember! My grandmother used to tell me about him in her riddles.

Slavaiah: (With commanding voice) fool! It was not riddle. It is sire qua non to know about the gospel truth that Satya Harichandra, a man of virtues, was transformed here where all the Gods blessed him.

Servaiah: How a nincompoop can get rid of his ignorance, stupidity and knavery in this obnoxious cursed land wherein people gather together and weep on the demises of their kith and kin!?

Slavaiah: Fool! This is the happiest place where human being becomes wise. Pay heed to my saying, this land is the amalgamation of varied human emotions. Here, we can study Rich and Poor, Clever and Stupid, Love and Hatred, Spendthrift, extravagant, miser, philanthropists, Rowdies, Exploiters, Womanizer, 
Lecher, Eunuch, so on and so forth. Each tomb has its own story. Do you know?

Servaiah: $\quad$ Since, I am very new to this place of wisdom. Your words are mystical. I have to perspire to acquire such wisdom here. But my stomach is overwhelmingly happy and idyll here in this state of being.

Slavaiah: Why!?

Servaiah: (With glee) In this blessed land, there is no appetite and starvation. Here is no struggle for survival and no quest for food. My death is bliss in guise for me which conquered the eternal starvation. Staying here is an idyll.

Slavaiah: Yes! Living in this burial land in tranquillity is better than living as a slave amidst the loveless world, neither hell nor heaven.

Servaiah: $\quad$ My friend! Why are you looking pale and dull in this griefless and painless land where is there is no hungry?

Slavaiah: (With grimacing and looking at Servaiah) My friend! Servaiah!! I am recollecting about my doleful and drab fate. I was deceived and killed.

Servaiah: $\quad$ Deceived! Killed .!!!?

Slavaiah: Richaiah, the Bale of Hariwada, manmetamorphosed-lion, assassinated me for no crime in that remote-vulnerable village. The residual ordeal has been remnant pestering in my heart.

(With astonishment, Servaiah thinks of his own assassination by the same Bale, Richaiah, in the same rendezvous of Hariwada. He is very eager and inquisitive to know the reasons behind the killing of Slavaiah, and later he also wishes to reveal the injustice induced to him after Slavaiah's revelation. His mind oscillates between Slavaiah's murder and his own murder.) 
Servaiah: (With a facial locution amalgamated with fear and wrath) Hh hhh Hariwada?

Slavaiah: Hariwada was a village where a throng of vulnerable knaves eked out for their survival. We were all babes in the hands of modernity during those days. All of us were the immigrants, including Richaiah, from different places. No one was educated in the village, except Richaiah, a semi-literate.

(Servaiah thinks that the village is the same and he wants to confirm whether the Bale, Richaiah, is the same)

Servaiah: $\quad$ Rrrr Richaiah!!?

Slavaiah: (He hits his strong fists against the dry banyan tree with rage and wrath, and his shaggy bosom shivers and quivers as he yells with rage. The burial land trembles and reverberates with quivering sounds of echoes because of his furious loud yell) The cunning Lion! Exploiter!! He is a lethal human-beast, womanizer, and a beast in guise of goat, who seduced as many beautiful women as he ogled at. All of us are the vulnerable knaves like mild Deer.

Servaiah: $\quad$ Please be resilient.

Slavaiah: He is six feet height with thick black eye brows. He is a black in complexion. In addition to that he is womanizer and lecher. He is an obese with a round belly. He who can change his colour to the tunes set by the circumstances like Chameleon.

Servaiah: (With an inquisitive mood) Wh wh. Wh why did he kill you?

Slavaiah: (Getting himself back to tranquility from faring up) Hh.. $\mathrm{mm} \mathrm{mmm}$ It is the gospel truth Servaiah. But I have been searching for appropriate opportunity to avenge Richaiah. Remember, every creature has its own time. 
Servaiah:

Slavaiah:

Servaiah:

Slavaiah:

Servaiah:

Slavaiah:

Servaiah:

Slavaiah

Servaiah:
(With grimaced and bemused locution) why did he kill you!? Reason? Please speak heart to heart.

It dated long back. It was the time when colonial hang over had been petering out. Emancipation, liberty, and independence had been replenishing and bouncing back into the lives of ex-slaves suffered under the colonial yoke. That was the period when Gandhi's philosophy of non-violence and non-cooperation was much talked about.

Hey! Eh! It sounds good. I also coddle and love Gandhian philosophy. But today, it is sad to say that its influence has been receded in the society. Sorry for the interruption. Then?

But, the indigenous colonialism was deeply rooted in my village, Hariwada where 'people go on drying their dirty bottom beside the reeking and stinking ditch of water when exploiters like Richaiah mushroom rampantly.'

(In nihilistic mood) Ooo Hhh Local landlords were more dangerous than colonizers. Right!?

There were two hundred conventional families with five hundred inhabitants in Hariwada. Among them, Richaiah is the one and only educated man hailing from higher social strata. We elected him as the head of the village. We, the Deer, abased ourselves the superiority of the Lion, beast poised.

\section{Elected! Is it through Democratic Election?}

(Nodding his head) Orally. We orally elected him. In fact, by that time, democracy and its traits were not penetrated into my village by that time. Democracy was not familiar to us. No leader had ever visited the village to enlighten us.

Then? How did you know about Gandhi and nonviolence and non-cooperation? 
Slavaiah: I used to go to the town market for selling paddy of Richaiah. In that market place people from different corners used to corral together and talk about nonviolence and non-cooperation of Gandhi, and the greatly revered democracy and independence.

Servaiah: (Sarcastically) Slavaiah! Slavaiah!! Oh $h h h h$ Democracy is a gauche today Do you mean Democracy!? By the People!? For the people!!? Of the people!!!? People are exasperated with democracy and tend to yearn for retrogation of Colonizer.

Slavaiah: (Repulsing Servaiah aside and retorting angrily) Ye!! Don't be ridiculous! Or else I will batter on your bottom.

Servaiah: (Retrieving himself back from vulgarity) be resilient! Cool! Cool!! We should not quibble about it. Today, people believe in that democracy is the exploiters' property. It is the treasury of rogues, and a watchdog in front of their properties. Democracy is, as if, the license to rogues, who are like parasites preying upon the rotten human bodies, to exploit and oust the poor today.

Slavaiah: $\quad$ No! You are in wrong notion.

Servaiah: But, you are adhesive to the stale and out dated belief used to be in vogue long back. Please let us forget about it and continue telling about your fate

Slavaiah: (Dipping his psyche into his apathetic personal annals) (pause) I was one of the slaves under the brutal control of Richaiah, a human-fox-lion The entry into his control is akin to entry into chaotic, bottomless, and dark hell.

Servaiah: How did you enter into that Hell of Satan, Richaiah?

Slavaiah: (Loitering towards his father's tomb) I was bulldozed to stay as slave under his pitiless crocodile-hold 
due to the blunder committed by my father by borrowing some money at the time of dire starvation. The debt mounted abundantly to zeniths and led to incorrigible.

Servaiah: How much money that your father borrowed from the animal, Richaiah?

Slavaiah: I was bequeathed with no lavish legacy of property, but the destitution and debt. My father took one thousand rupees from him when there was dire starvation which killed many in destitution including my father. But I paid one hundred rupees monthly to get rid of his tyrannical control and to relinquish myself and absolve from the debt, besides, working for him from dawn to dusk as equally as castrated oxen. The testicles truncated oxen expect grocery of the master after work: we expected for food and never ensuing emancipation.

Servaiah: (With little surprise) where did you get one hundred rupees per month from? Are you a burglar?

Slavaiah: (Scowls at Servaiah seriously and paces with pauses towards his wife's tomb, and succumbs to the grave) (weeping) No. No No. My wife, Siri, a beautiful woman, used to cobble at my half built hut. She used to earn a little money daily through her handcraft. (With sapless voice and moistureless lips) But she (He weeps and screams, yells loudly in grief. The whole grave yard echoes).

Servaiah: $\quad$ (With dilemmatic mind) What happened to $h . . h \ldots$ her? Please reel it out!

Slavaiah: (The atrocity and anomaly induced by Richaiah has been lingering in and pestering heart as eternal burning ember. He recollects those idiosyncratic humiliations which are like adding on fuel to the burning embers. Slavaiah roars with rage and wrath as if a lion roars in dire hungry) 
SEDUCTION! And ASSASINATION!! By a stray dog, and human-beast. He seduced as many beautiful women as he ogled at including my sweet heart, Siri O! God! I was unable to fathom out his true nature.

Servaiah: $\quad$ (Thinking in himself of injustice done to him by Richaiah which he wants reveal later after Slavaiah) you should have killed the bastard, a reprehensible nincompoop, a human beast! How he did advance to commit this grave social anomaly?

(Slavaiah goes deep into his personal annals reminiscing about anecdotes occurred in his life.)

Slavaiah: (Bouncing back to the normality, tranquillity, and reminiscing about his wife, Siri, with aesthetic and romantic mood)

(It was the day of celebration of local carnival. Everybody was colourful with new apparels. The whole village was decorated with kaleidoscopic colours and glittering adorations. I and my wife wore new cloths. She was like an angel who was emanating amidst the rose flowers plethora. (In romantic mood, Slavaiah sings a song aiming at Siri's beauty )

Slavaiah: $\quad$ A babe in the wood, Oh! My beauty!

Siri your drooping eyebrows

Are like black spectrum of rainbows.

Round vermillion amidst either eyebrow

Is like rising dawn that permanently pauses.

Thick black eyeballs and its white surface

Are like stars in sky and the eyes-surface promises peace.

Nose is, as if, a vertical scar

That made up of fallen star.

The ear rings that fall and sway

Resemble the Lily flowers every day.

The scattered stars that form in a row

Adorn your neck to grow your glow.

The Jasmines are like bloomed moon amidst 
your hair

And boast themselves as your legal heirs.

The modest bosom in glee

Is, as though, like the lovers' tryst in spree.

The stretched sari in free

Is like outstretched dappled sky in its spree.

Thick hairs up to your thigh beneath

Are like the black cloud reaching to the earth.

O! Siri i i i my dear!!

You are everywhere

Servaiah: $\quad$ Stop! Come out of the dream. Tell me how she was killed?

Slavaiah: $\quad$ Servaiah! We used to sacrifice unblemished goats to our local deity to appease her wrath. If the local deity demands human sacrifice, we obey and abide by that command of the deity. It was our traditional custom. Further, it was part and parcel of our indigenous culture to give gifts to the masters on the day of local carnival. My wife, with her tender hands, toiled and moiled to cobble a pair of shoes to gift Richaiah.

(Servaiah becomes furious by hearing "the human sacrifice". He shouts in stentorian voice: "Superstitious sentimental fools! Barbarians!! These are Knaves prone to traditional customs". He again thinks of the injustice happened to him)

Servaiah: Had you gifted the pair of shoes?

Slavaiah: $\quad$ Yes! We did, but that jiffy was bad omen for me.

Servaiah: $\quad$ (With bemused slitter) How?

Slavaiah: (Amidst the grief sounds of the chorus of invisible spirits, Slavaiah with apathetic voice) Richaiah had shown his promiscuous-natural behaviour by casting his ogling and vulgar eye upon my wife. He barged into my desolate hut and manhandled her to sleep with him. There was scuffle between 
them. At last the senseless beast won the game and seduced her. When I entered into. (pauses, weeps)

Servaiah: (Servaiah responds) we, the knaves, are letting him do such immoral, illegal, and illegitimate things. Tiger kills the unblemished and innocent mild animals in the forest for its prey. It is natural and justifiable because they are senseless animals. But, we are human beings must stick to ethics and moral values.

Slavaiah: (with low and hoarse voice) When I entered into the house, she was unconsciously prostrating herself on floor with naked body with full of blood scars all over the body. The last word she spoke was 'R Rrrr Richaiah is the beast'. I started to tread to kill the bastard, but my wife, who was on the verge of last breath, clasped my hand, stopped me and said "execute it by choice not by chance".

Servaiah: $\quad$ (with low voice and with grief) O! God!! Why did you permit such human animals to hang and laze around the society? Where your retribution is!

Slavaiah: (weeping and showering drops of tears) Do you know? It happened at the time when my embryonic heir was in her womb.

Servaiah: It is heartbreaking for me to know the triple murders that the human-Lion killed both your wife and your embryonic heir in one go, and later yours killing

Slavaiah: (thinking deeply) I was waiting for the appropriate time to avenge and quench my thirst with his cold blood. Further, I worked under him as though I did not know seduction of my wife.

Servaiah: He also deceived you Is it right?

Slavaiah: (With loud voice) True! True!! True!!! He deceived me by poisoning the food.

Servaiah: Poison!!!!? 
Slavaiah: As usual, after the work, the food was arranged to all the slaves in the ambience of Richaiah's palace in the evening. Everybody went home, but I slept with paralytic body amid the hodgepodge of food. I try to move, but in vain. Richaiah came to me and lifted my head with his toes. When I was on brim of last breath, he flouted "I do not want to have any enemy like you. I know that you are waiting for time to kill me. Therefore, I poisoned your food. Die! The outcaste!! The bastard!!! Slave!!!!"

Servaiah: Man eater!

(He yells with full of apocalyptic ire as to reverberate the whole grave yard. Slavaiah surprises to see the queer response from Servaiah) Brother! Comrade! The same Richaiah did the same kind of injustice to me also.

Slavaiah: If so, are you from Hariwada?

Servaiah: $\quad$ Yes! You were killed by Richaiah before my genesis. I have been killed by my own kith and kin and sibling, the superstitious barbarians who are, the puppets in the hands of the master, prone to wild traditional customs,.

Slavaiah: How!?

Servaiah: There was a foxy strategic plan of Richaiah behind my brutal assassination by my own people.

(The cocks cooed Kokoroko Kokoroko Kokoroko which indicates the ensuing dawn)

Slavaiah: It is about to dawn.

Servaiah: It is the time for us to disappear. I shall share my fate with you tomorrow night. We shall disappear, Slavaiah.

(The couple of spirits are invisible on the stage when the dawn kills the darkness) 


\section{Act I}

\section{Scene II}

(On the stage, in front of Richaiah's palace, there is a throng with hefty decorations. Some women are balancing the decorated pot on their heads. The pots are with dappled and multi-colours: red, white, and yellow. Every pot consists of neem branches which is called "Bonaalu" in their colloquial language. There is trio of drummers drumming the traditional drums with accelerating beat. The women are performing the traditional dance to the tunes given by the drummers. There is unblemished goat decorated with myriad of colours and clasped with heavy garland around its neck. A crooked black man with heavy belly is carrying a rope anchored around the neck of the xenophobic goat which is afraid of the heavy mob. The dancing women consumed excess of toddy. The barbarous throng paces towards the out skirts of Hariwada, where the local deity's temple is situated, to sacrifice the unblemished goat to appease the wrath of "Dungamma", the local deity. The procession reaches the palace of Richaiah. They are ready to receive Witchamma, who is clad-in wild-red attire, the wife of Richaiah. The local people believe that Dungamma possesses Witchamma. Richaiah and Witchamma are discussing in their palace regarding the pronouncement and demand of sacrifice this year. Meanwhile, Raydudu, a thief, comes to Witchamma and reveals the theft done by him in Sita's house and bows before her in repentance. Rayudu leaves the palace and joins the mob. Action is inside the palace.)

Witchamma: Who is the scapegoat this year? Whom should I demand for sacrifice in the capacity of possession and impersonation of deity?

Richaiah: (Frowning at the rampant mob through the window ajar) Revulaiah!

Witchamma: Revulaiah!!!. (She was deeply in one side love with Revulaiah for quenching her lustful Eros) Why not someone else?

Richaiah: He seems to be the danger and the pain in the neck of our power in this village. He is enlightening the mob to rebel against our control. We were succeeded in killing Servaiah, who imparted revolutionary instinct in the knaves, last year. Hence, there won't be tremendous or overwhelming 
nod for the excommunication of Revulaiah. Be careful!

Witchamma: So, this year Revulaiah is going to be assassinated as scapegoat. Am I Right?

Richaiah: No no not sacrifice, but excommunication. We shall expel and excommunicate Revulaiah from this village.

Witchamma: So, I find a false reason and I demand for excommunication of Revulaiah this year.

Richaiah: Remember! We have not come to this stage not by a single stroke of fluke, but by dire exploitation and flux of massacres. The revolutionary instinct must not mushroom in these stupid and superstitious minds.

(Witchamma comes out of the palace with quivering bangles' sounds and heavy velocity of traditional tribal dance with leaps and bounds. She bounces all of sudden with horrifying, roaring, and long panting. Her broad vermillion amidst her broad forehead has been scattered wild. She clasps the neem braches in either hand.)

Chorus: (The ordinary women folk reiterate and proclaim) Oh! The goddess!! Deity!!! Dungamma is so furious. Ma ma. Mama What do you want this year? What is the good word this year?

Witchamma: (In guise of deity with wild shouts) Jajzzanaku Jzjana ye ! There would be dearth of rainfall this year!

A few of folk: (There is commotion among the folk. They whisper to each other: we have to appease the wrath of the deity). Ma ma What should we do to make you happy?

Witchamma: I would let you later. But very first mandatory is that everybody should accept the control of Richaiah or else I would shower an unpredicted curse after a curse upon you. I invisibly batter you on to death with repeated plagues!

(During her dance with leaps and bounds, the lemon pricked to the hatchet is lost) 
Some Folk: (Pause in commotion) Hey! Bad omen!? Bad omen!? Look at that there is no lemon adhesive to hatchet of the deity? Ma ma Where is it?

Witchamma: (In guise of deity) Yeeee yooyoooo Re Richaiah! Come here. (Richaiah comes to her. She whispers in his ear that "I put lemon beside the potable pot after cooking was over. Go go go bring it"). Yee !hh Richaiah! Pay heed to my saying that the lemon is beside the potable pot in your house. Go and bring it fast Go

Folk: $\quad$ (Some women shout loudly) Maa ma what a mighty and sublime power you have! We are very much impressed by your sublime soothsaying!

Witchamma: Yee ...hu ...hu ... Rey Rayudu. You have burgled the ornaments and money of Sita a couple of days back. Go! Return her ornaments and money to Sita! (Rayudu had already accepted his burglary before Witchamma, but nobody knew it)

All the Folk: (With one nod and one voice) Oh! The deity has sublime power! She can foresee calamities and hazards. It is the gospel truth that she is real deity.

(The procession reached the temple's altar amidst the heavy drumming beats with wild tribal dances. They shout: respect the deity! Hack out the throat of this unblemished goat!)

Witchamma: (Trembling) Servaiah has been disappeared last year. Is it right?

Folk: $\quad$ (All at once) Yes! Ma ma ma Thalleee

Witchamma: He fought against the local landlords directly and against me indirectly. He illegally occupied this temple's land Is it right?

Folk: $\quad$ Yes! True! True!!

Witchamma: Ye! He made that inexcusable crime. Therefore, I made him lunatic. He killed himself in the red-dead well which is on the verge of the burial land. 
Folk:

(One elder women from the women folk) Thalleee, $\quad \mathrm{Ma}$ ma She can see past and future! Ye! Praise her with utmost reverence! Ma There are no symptoms of herald and promise of rain fall so far this year. It seems that monsoons are totally failed. How would be the crop this year?

Witchamma: Stupid people! Hi hi hihihi There would be starvation!, No rains! No prosperity! No crop! Just because of one man.

Folk: (an elderly man) who is he, the curse to this village?

Witchmma: (with wild face and broadening her eyeballs) Revulaiah He is seducing and corrupting your indelible hearts by cramming new thoughts into your minds. He is talking against my power without any iota of respect and reverence in me.

Folk: $\quad$ (A few elder women shout) Ma Thalleeee. What shall we do with that man? Shall we sacrifice him as a scapegoat?

Witchamma: no any sacrifice, but expulsion from this village!

Folk: Revulaiah should be expelled. Ye Search for Revulaiah Where is he?

(There is commotion in the throng. Some voices are loud: Excommunication Expulsion Revulaiah) (They shout: respect the deity! Hack out the throat of the unblemished goat!) (They hacked the unblemished goat's head off. A stream of hot blood of the slain goat flows and touches the legs of Witchamma.)

Witchamma: Ye! Hay hay ha yyya! I am happy. You have appeased and alleviated my grave appetite through the sacrifice of the unblemished goat and through the expulsion of Revulaiah. Therefore, you are going to get abundance of crop this year I bless you

(She falls all of sudden on the ground and gets up after a short while to reveal that the impersonation of the deity is over)

(In the afternoon, all the elderly people gather together to proclaim and pronounce the word of the deity: Excommunication Expulsion All the 
ordinary folk also hang around the vicinities of the temple to judge Revulaiah. Severe blows are meted out to Revulaiah by the superstitious people. Richaiah sits amidst the crowd. Revulaiah is brought by them forcibly to face the arbitrary arbitration.)

Revulaiah: (With rebellious voice, insatiable and uncontrollable emotion. Panting) why have you brought me here?

Richaiah: People believe in it that you are the curse to this village.

Revulaiah: What sort of curse I have committed to this village?

Richaiah: On behalf of Dungamma, our sublime deity, we gather here. Dungamma does not yen the people with seductive mind like you. (Ordinary folk shout with accelerated voice: Yes!Yes! ExcommUUUUUUnicaAAAAAtion! Excommunicate him!)

Revulaiah: (Shouts) You! Barbarians! Stop it!!

Richaiah: $\quad$ Peace Peace Peace . My dear people! Please maintain silence for our deity's sake. (There is little pause).

Revulaiah: Is enlightening the people about the superstitions a curse?

Richaiah: This village has its own customs and traditions. Who are you to stop and root out the deeply rooted beliefs?

Revulaiah: (With reproved voice) Out dated, age-old, and rotten customs! Ye, Customs are framed and structured by us, but not the customs carved out our lives and fate. Customs are ever dynamic. They ever change to lead us towards peaceful life.

Richaiah: Our deity said "Challenging the customs and traditions is the $\sin ^{\prime \prime}$.

Revulaiah: Who told it? (With sarcastic levity) Your wife, the catty vixen!? Not the people! Is it right?

Richaiah: $\quad$ Not my wife, but 'Dungamma', the deity, on behalf of the people of Hariwada. 
Revulaiah: Dungamma!? the deity!? How did she know my name?

Richaiah: She is goddess. She knows everything.

Revulaiah: Can she name everyone in this Hariwada?

Richaiah: (With dilemmatic and question mark face) This convention is not to listen to your oration, but to execute the deity's judgment to get abundance of crop this year. Deity foresaid and promised the hefty crop at the cost of your excommunication.

(Ordinary folk shout: Yes! Deity said.)

Revulaiah: Ye. Fools! Monsoons are so weak this year! I heard it through the radio. In correspondence to monsoons, there would be starvation this year.

Richaiah: You are humiliating 'Dungamma' again. Stop ridiculing or else

Revulaiah: Or else what? Your further plan is to kill me. Is it right? Kill me right now. I shall mushroom and come out with thousands of revolutionary voices aftermath of my assassination. Each drop of my boiling blood shall beget thousands of warriors and enlighten the innocent minds of thousand slaves to rebel against you.

Richaiah: (Richaiah shouts) "Stone the bastard! He does not yield for the good words.

(Indecorous mass hurled stones aiming at his body and head. A few big stones hurt the forehead of Revulaiah causing a flux of blood. People hit him severely till he falls unconsciously. During the night, he wakes up uncomfortably and moves towards the burial land thinking about the humiliation caused by his own sibling, kith and kin.)

\section{Act I}

\section{Scene III}

(The scene moves back to the burial land where in the two spirits, Slavaiah and Servaiah, gathered together again in the night. 
Servaiah reveals the injustice and humiliation induced in the hands of Richaiah)

Slavaiah: Servaiah! Let me know your sapless and doleful experience. Speak out and reveal!

Servaiah: There was five acres of waste land beside the temple of the local deity, Dungamma. The land was replete with obnoxious weeds.

Slavaiah: It was temple's property? Is it not?

Servaiah: Yes. But Richaiah, with his crooked bent of mind, planned to grab the temple's land because this land is beside his fertile land.

Slavaiah: What did you do with that waste land?

Servaiah: I laboured a lot to weed out the obnoxious weeds and to root out the wild trees by taking much risk.

Slavaiah: For what? For cultivation?

Servaiah: Yes. But my hard work to make the waste land fertile irritated and ignited wrath to Richaiah because he wanted to occupy this land.

Slavaiah: That bastard might have employed strategic conspiracy! Right!?

Servaiah: (with desperate mood and dripping drops of tears) Yes You are Right? I toiled and moiled along with my destitute family to fertile the land, but in vain. We hardly reaped one crop.

Slavaiah: (Eagerly) what kind of unethical trick employed against you?

Servaiah: It was on the day of local carnival. Richaiah persuaded Witchamma, who pretended the possession of Dungamma, the deity, to claim the barren land-turned-fertile land.

Slavaiah: The barbarian and superstitious knaves of Hariwada might have stringently supported her arbitrary arbitration. Right? 
Servaiah: Rebelling against the verdict, I sowed seeds in that land amidst all the disapproval of the villagers. It infuriated Lion-Man, Richaiah.

Slavaiah: (Outburst with an uncontrollable voice). The gospel reality is that if the rebellion mushrooms rampantly, there would be an equal share of brutal massacres to abate the rampant revolutionary instinct. Rebellion costs sacrifice! Sacrifice!! (pauses).

Servaiah: (weeping and abusing Richaiah) Richaiah unethically and brutally assassinated me when I was alone in my crop field during a night. When I was on my way back to home, he hounded behind me and hit with heavy iron rod. Later he pierced into my heart and bottom till I die. No one of the villagers knew it.

Slavaiah: (with a panicking face) Oh! Oh!! .huu My God!! What a brutal killing is this!!!!

Servaiah: Later, he dragged my dead body to this burial land and earthed my slain body leaving no clue to my death.

\section{Act I}

\section{Scene IV}

(The two spirits are sadly sitting thinking about their fate, but they are hopeful that goodness wins over wickedness at the end. They are in ferocious mood taking cudgel against ill-treatment caused by Richaiah and craving for some hope that rises like dawn, which redeems them from their gruesome and gloomy state of being, in their doleful lives,. As they are eagerly waiting for hope, they hear the sounds that are gradually becoming loud far away. They peeped at a person barging into the burial land. Revulaiah barges into the burial land with soiled cloths, scars of blood. He stammers, trembles, and wobbles. There is no bloodless speck on his body. His lips are moistureless and his body is sapless. He is hopelessly and desperately gibing, chiding, and cursing his own fate caused by his own superstitious sibling. As he comes near to the red-dead well to kill himself, he sings in philosophical way)

Revulaiah: I am in trance indeed. 
I turned mad.

I barged into this burial land

To succumb to the peaceful death bed.

I have no abode

O! Lord!! Send your proxy

O! Lord!! Send your proxy

He (Christ) who was misjudged at his age of thirty,

The rescuer and consoler of my calamity

Please! Absolve and exonerate me from apathy

Posthumously, even after submerge in red-dead well.

For an infant, the mother is the rescuer

For eyeball, eyelid is the rescuer

For the human body, the conscience is the rescuer

But, for me!? My stream of tears my flux of tears.

And my happy death

Hey! death! I wait for you like a lover

Who waits for the first kiss of beloved?

(The buoyant spirits appear before Revulaiah)

Revulaiah: Who are you?

Slavaiah \&

Servaiah: (both voices together) we are, Slavaiah and Servaiah.

Revulaiah: Why do you scowl at me? I am untouchable! I am an excommunicated and expelled traitor! I am inexcusable sinner! Don't touch me!

Slavaiah \&

Servaiah:

(both voices together in one voice) we are buoyant spirits.

Revulaiah: $\quad$ Spirits !!!? I do not have macabre fear. I am not afraid of you because I am also going to transform like you after a while. Let me join you don't stop me!

Slavaiah: $\quad$ Suicide? Self-killing is crime and sin. Is not it?

Servaiah: (Sarcastically) Revulaiah! Are you a coward?

Revulaiah: (With fulminating voice) who is the coward? Is it me? 
Slavaiah \&

Servaiah:

Yes! Your attempt of suicide is symbol for your cowardliness. Suicide is cowards' weapon.

Revulaiah: Don't rebuke and irritate me. I know all about it. But I am in desperate situation. Many eminent people chose suicide to free themselves from their despair. Let me die!

Slavaiah: Suicide fetches nothing. The duty of the human kind is to struggle for reaching the set goal. Do not be unnerved!

Revulaiah: I tried to reach my goal, but in vain. I tried my best to create awareness on superstitions among the vulnerable and barbarous people. My attempt was resulted in humiliation to me. I was prone to wicked trickery of indigenous land lords. It is gospel truth that the colonial hang over has been percolating from generations to generations directly or indirectly.

Servaiah: $\quad$ (Looking at Revulaiah) Think not of suicide! Live and take revenge against the idiosyncratic injustice bestowed upon you by your enemies.

Revulaiah: My doleful and apathetic mood does not synchronize with your philosophy. I incline to rest in the tomb forever Please! Leave passage for me, I yen to die!

Slavaiah: Who is the wicked bastard excommunicated you even for the right work?

Revulaiah: I do not bother about my excommunication by the Bale, Richaiah, but my own siblings' hatredness.

Slavaiah \&

Servaiah:

(with furious shaggy bosom) Rrr Rrr

Richaiah!!!? Richaiah of Hariwada!!!!?

Revulaiah: Do you know that stray dog, Richaiah? 
Servaiah: We were killed by him. That is the reason why we were transformed as buoyant spirits. We have been waiting for a long time expecting the herald, hope, to take revenge against his ill-treatment caused to us.

(They loiter on snail's pace towards the dry banyan tree edifying the mind of Revulaiah. They wish to use Revulaiah as barbed weapon to end Richaiah. For them Revulaiah is the rescuer and savior in their hopeless state.)

Slavaiah: (Rekindles Revulaiah with a provocative voice) Revulaiah! Do you wish to take revenge against Richaiah?

Revulaiah: (With a big loud voice) yes! I would kill the bastard brutally with barbed traditional weapon.

Slavaiah: No no no. not with violence, but non-violence, and non-cooperation. These are the sharpest weapons than barbed spheres and swords.

Servaiah: Yes these are Gandhi's weapons. With these weapons, Gandhi freed us from the foreign tyrants.

Revulaiah: Gandhi also said “Do or die!" I do kill the bastard, Richaiah or else I die!

Slavaiah: $\quad$ You are retrogressive! No no do not mistake and misinterpret it. To instill and ignite a firm commitment in our minds and to expel the British, Gandhi called for "Do": Struggle to expel the Colonizer "Die": Till our last breath.

Revulaiah: Stale platitudes! State platitudes!! Stale platitudes!!! I tried the weapon of non-violence, but in vain. Gandhi's philosophy is out dated now. That does not work these days. 'Thorn shall be taken out by thorn only". "Violence begets tranquility" as was in Ramayana. Be violent to be peaceful!

Servaiah: (looking at Slavaiah) It is imminent that Revulaiah is the herald who can make people of Hariwada free from the clutches and shackles of Richaiah. 
Slavaiah: Is he our saviour!? Whom we are searching for?

Servaiah: May be, he is incarnated Gandhi second time to establish peace through the weapon of violence .

Servaiah: Ye! Look at the spark coming towards us with sonorous agog drone

Revulaiah: Is it another spirit coming to join us? Peer at the gigantic image of blaze!

Servaiah: Oh! My blood is boiling with scorching heat by listening to the exciting voice.

Revulaiah: My nerves are petering out to rigidity to listen to that voice. Ye! the image is coming towards us with cigar in his hand. Look at the fog-like smoke!

Servaiah: That is not fog, but smoke.

Slavaiah: Who is he? Let us gaze and peep at him!

Servaiah: $\quad$ Ye! He is also a spirit, but I had never seen this spirit in this happiest place (graveyard) where there is no starvation .?

Slavaiah: Oh! I think that this spirit roams rampantly everywhere without any pause to ignite and enlighten the stupid minds and people who are devoid of happiness in this rotten society.

Revulaiah: Ye! The inspirable and agog voice comes nearer. Let us be silent and listen to the penetrating slogans which are piercing our hearts. I hope the sounds are of Sri Sri. (The voice gradually becomes louder:

The agog: Rejuvenate and perk up yourselves! Fend for yourselves!

voice March forward,

Another world engulfed with morality,

Is calling you!

March forward!

Forge and surge!

We shall surge up to the zeniths.

Rotten bones, 
Old aged,

Lethargic youth! Die!

Dazzling and boiling blooded,

Youth of power,

You are the soldiers

March fast

Roaring "Harom! Harom! Hara!

Hara! Hara! Hara! Hara! Harom Hara!

Surge and forge!

Like roaring knights in the battle,

With full of rage and wrath

Like the dreadful sounds of the tempest,

Pela, Pela, Pela, Pela bounce upon the evil!)

(The voice recedes and the image pares down )

Revulaiah: (In emotion and with quivering shaggy bosom to avenge Richaiah). To bounce upon the evil like a thunder and spark, the non-violence does not suit. The voice inspired me propelling me to bounce upon the Lion, Richaiah. The voice is like add-on fuel to my instinctive revenge.

Slavaiah: No, no, no, violence, but trickery and conspiracy which can be used as boomerang to Richaiah. Customs and traditions are to elevate people, but the same customs and traditions are like barbed traditional weapons to devastate and annihilate the exploiters.

Servaiah: Don't stumble on idiocy! No, no, no, violence, please! Think for another avenue.

Slavaiah: (Engrossing on employing a trick) A Trick can be overcome by only trick. There is no other way because crying in abyss for years together against the heartless-limitless suppression proved futile.

Revulaiah: Yes! "Tit for tat"! We have to win the tricksters by employing tricks upon them.

Slavaiah: Revulaiah! If so, have you found any personal flaw in Richaiah? 
Revulaiah: I found a flaw not in him, but in Witchamma lest leads to the end of Richaiah.

Servaiah: (With anxiety) what is it!?

Revulaiah: As Witchamma is crazy to be cozy with me to have promiscuous and indecorous relation with me, she bulldozed me many times, by hook or crook, to satisfy her lust through illegitimate way. She is even ready to deceive her husband, Richaiah, for my sake.

Slavaiah: Good opportunity is before us! Go with this wellorganized plan to avenge Richaiah, but with much prowess and knack.

Servaiah: Revulaiah! Allure and propel Witchamma towards the promiscuous and illegitimate contact to deceive her own husband, Richaiah.

Slavaiah\& (thinking that they could completely revolutionized Revulaiah)

Servaiah: All the best! Richaiah deserves the punishment Go ahead!

Revulaiah: Oh! Your blessings doubled my strength.

\section{Act I}

\section{Scene V}

(As has been the traditionally pernicious and lethal dogma of excommunication in vogue, Revulaiah does not enter into Hariwada. He lives in a small hovel at the outskirts of the Hariwada like a deceived tiger waits for opportunity to bounce upon its prey. As everyone in the village whispers about the return of the Richaiah, Witchamma listens to the whisperings and goes secretly to the hovel of Revulaiah.)

Witchamma: (Ogling at Revulaiah) how are you my dear?

Revulaiah: (With flirting look) Not bad but the wounds caused by the stones are paining even today. 
Witchamma: (Ogling at Revulaiah) I flirted and pressurized you for many times to satisfy my lustful desire. But, you did not pay heed to my requests. Your present painful state is because of your ignorance and self-made flaw.

Revulaiah: (with sober voice) I hesitated to do it because you are hailing from a rich family.

Witchamma: (Leaving the veil aside, opening breast) Sexual satisfaction is sublime satisfaction over all the satisfactions for me. I reiterate again that I shall give up, relinquish and deceive Richaiah for your sake.

Revulaiah: (Ridiculing and mocking the words of Withchamma) is it love or Infatuation, or sexual perversion!?

Witchamma: (Opening the breast and twisting her tender lips) whatever you deem it, it is none of my business. My business is to have and crave for sexual satisfaction from you (with husky voice) forever.

Revulaiah: It is a dream. You may not get that satisfaction.

Witchamma: (With loud voice) Why!?

Revulaiah: (Thinking deeply for employing and executing a wicked trick) Because, Richaiah is a big hurdle and problem between us.

Withamma: (With an angry facial grimace) See! Revulaiah!!? Do not kindle and rebuke my deity-power and capacity. People believe in me as the local deity, Dungamma. Whatever the filthy word I pronounce that metamorphoses to ecclesiastical dogma.

Revulaiah: What do you mean?

Witchamma: (With lustful and husky voice and moving towards Revulaiah) I mean (as if she boozed and sexually seduced mind) that I can go at any extent for your sake, but not even God's sake. I die for you. Please batter on my sensitive breast to your shaggy bosom and arrest me with your iron hands! 
Revulaiah: (Seizes, hugs and clasps her curvy waist) Oh! How beautiful you are! Whole the beauty of the nature is not equal to you.

Witchamma: How happy your hug is. If you promise me to stay with me forever, I use a trick, 'boomerang' on Richaiah.

Revulaiah: (with dire eagerness) I promise you that I will be with you forever. But what is your plan of action?

Witchamma: I act on your concern. I act upon at the behest of your assurance. I employ the same 'boomerang: Excommunication' upon Richaiah. You are going to see that this superstitious people chase and haunt him hurling stones against him until he reaches the burial land.

Revulaiah: (With facial revulsion and disgust on the face) Good! Execute your plan of action perfectly or else he kills both of us.

(As Revulaiah flirts with Witchamma, she comes nearer to Revulaiah. He fondles and kisses her broad forehead, which is as though an ocean of space, as a token of ensuing promiscuous relations and gently touches her bosom so as to make lustful desire rampant. Witchamma goes out of hovel with the same continuous tempo. Adjacent to the temple's altar, she appears in red clad-in attire with a few neem branches on her either hand pretending that Dungamma abruptly impersonated Witchamma to announce the oncoming calamity to this village. All the villagers are ordered to gather together immediately at the radius of the temple. Villagers crowded at the temple within a few minutes.)

Witchamma: Rey. My people!! I predict the oncoming calamity and disaster. There is no promise of monsoon so far despite I promise the copious crop this year.

Folk: $\quad$ (Some of the folk in the crowd) yes Ma ma you told it, but it has not been fulfilled.

Witchamma: (wobbling) I regret my decision. I excommunicated and repelled my staunch supporter, devotee Revulaiah who is living as recluse at the outskirts of this village, Hariwada. 
Folk: $\quad$ Yes! Thallee. We executed your order and tribalecclesiastical coquette.

Witchamma: Ye .. yhhuuuu But the Yerukalaiah, the God of all local deities, and my eye-opener, is angry on my pronouncement of excommunication Hence, I come back to rectify it.

Folk: What is the rectification? Ma...ma.

Witchamma: Revulaiah ah a ah committed no crime against me, but became scapegoat to Richaiah, said Yerukalaiah.

Folk: $\quad$ (A few of the crowd) Richaiah!?? The Bale?

Witchamma: Richaiah! He is an atheist and traitor. He did not pay reverence and respect to my power.

Folk: $\quad M a$. He is the bale of this village.

Witchamma: Ye! Who is that stupid uttered nonsense? You know! All are equal before my love and rage. (Pause) The pious property related to my temple became impious. Look at my land! Half of my land, which is amalgamated in Richaiah's fertile land, is forcibly and illegally encroached by Richaiah.

Folk: $\quad$ (Looking at the land) Yes! Ma True! The pious land has been impious with his illegal encroachment.

Witchamaa: As a result, you are going to prone to dire starvation this year

Folk: $\quad$ (Sophomoric whisperings) what shall we do to escape from this oncoming calamity?

Witchamma: Ye! My judgment of love, wrath, and punishment to the Bale also is on a par with ordinary folk. I made Servaiah mad and killed him just for the trivial attempt of cultivation of my pious land

Folk: $\quad$ Yes! You told it on the day of carnival!

Witchamma: Hho Ooo. I declared and pronounced excommunication upon Servaiah. 
Folk: $\quad$ (More submissively) The deity ordered us for the sake of our betterment! We have to follow her command!

Witchamma: (Looking at the crowd) Let me tell the Yerukalaiah's order that Revulaiah is flawless. Invite him back into this village.

Folk: (Cacophonic sounds are heard as if it is a public brawl: Surge and forge' quest for Richaiah, the traitor) Oh! Very good revelation!

(Witchamma falls on the floor for a while and gets up to pretend and reveal that impersonation of Dungamma is over. Furious are the Hariwarda's superstitious people and brought Richaiah and made him sit amidst the crowd. Richaiah fulminates and rebuffs.)

Folk:

(Roaring loudly) Hey! Ye! Hurl and fling stones towards him aiming at his body.

(People start to fling stones aiming at him. People banged with their tight fists calling him 'traitor, mad-man'.)

Richaiah: (In his trance and amnesia) Eh! Right are my insane words! Listen to them! The souls of the vulnerable people killed by me are happy forever and they have life in death, but the killers like me, who has been suffering from the eternal guilty, have death in life.

Folk: $\quad$ Richaiah! The traitor, mad-man". Ye! Hurl stones at him!! (A big stone hurled by a young-strong man hits severely one of the temples of Richaiah resulting in him the real madness. Then Richaiah really turns to be mad. He is ugly with drooling saliva and dripping blood)

Richaiah: (As if boozed in his mad situation) ye! You are my subjects and I am the king. Do not hurl stones at your king.

(As the people chased him to the burial land, he trespassed and barged into the burial land.)

Richaiah: (talking and murmuring in himself looks at the bones) Hi. $\mathrm{Hi}$ hi hihihihihi. What is this? It (leg bone of skeleton) looks like my sword. (He clasps the bone and whirls it unevenly in air. He goes to a tomb, sits astride, 
calls the tomb his horse, and rides on the tomb as though the tomb is a horse. The heavy drum beats are heard afar.)

Richaiah: (Revolving and turning around himself haphazardly) Hi. Hi hi hihihihihi. Oh! My horse! Move move move chall Go fast with an accelerated velocity. Hey! Horse Chal chal challlll Why you are moving on snail's pace. Nice! How good your rhythmic velocity is!

(He gets down and looks at a skull agape. He keeps the skull on his head and calls it 'crown'.)

Richaiah: (Looking at skull) what is it looking white? Oh! It is my crown! Oh! I remember I am the king! I crown it! Where is the feather, Kohinoor diamond, on my crown?!

(Later he collects all the rotten bones and skulls from the rotten corpses scattered around the graveyard. He arranges them in a perfect array to make a bony garland, which is heaped upon his body is more than his body weight. He ties pelvis and Ilium to the bony garland as dollar and he wears it.)

Richaiah: Oh! It is my garland! Right? I wear it. (He wears the bony garland) $\mathrm{Hi}$ hi hi hihihi Now I enter my Kingdom! Where is my army? Where are my people to welcome me though I am returning from the victorious battle?

(He moves in heaps and bounds towards the red-dead well which enthralls everyone to grab )

Richaiah: $\quad$ (Stands on the verge of the red-dead well) Oh! Hi hu hu. huhuhuh Oh! my Kingdome is red! I jump into it. I dive into it I rule this red kingdom

(Richaiah kills himself in his mad state.) 